\title{
STRATEGIES TO COMBAT POVERTY AND THEIR INTERFACE WITH HEALTH PROMOTION
}

\author{
Simone Helena dos Santos Oliveira ${ }^{1}$ \\ Maria Adelane Alves Monteiro ${ }^{2}$ \\ Maria do Socorro Vieira Lopes ${ }^{3}$ \\ Daniele Mary Silva de Brito ${ }^{4}$ \\ Neiva Francenely Cunha Vieira ${ }^{5}$ \\ Maria Grasiela Teixeira Barroso ${ }^{6}$ \\ Lorena Barbosa Ximenes ${ }^{7}$
}

Oliveira SHS, Maria Monteiro AA, Lopes MSV, Brito DMS, Vieira NFC, Barroso MGT, Ximenes LB. Strategies to combat poverty and their interface with health promotion. Rev Latino-am Enfermagem 2007 setembro-outubro; 15(número especial):867-73.

The population impoverishment is a social reality whose overcoming is necessary so that we can think about health as a positive concept. This study proposes a reflection on the coping strategies adopted by the Conjunto Palmeira, a Brazilian community in the Northeast, and their interface with health promotion. This community's reality is an example of overcoming social exclusion for different regions of Brazil and other countries. The history of the Conjunto and the collective strategies of empowerment for coping with poverty and search for human development are initially presented. After that, we establish the relationship of those strategies with the action fields for health promotion. Finally, we consider that the mutual responsibility of the community with its health and its relationship with the environment in which they live are means of promoting transformation towards the conquest of a worthy social space.

DESCRIPTORS: health promotion; poverty; nursing

\section{ESTRATEGIAS DE AFRONTAMIENTO DE LA POBREZA Y SU INTERFAZ CON LA PROMOCIÓN DE LA SALUD}

El empobrecimiento de la población es una realidad social cuya superación es necesaria para que podamos pensar en salud como un concepto positivo. Ante la realidad que se muestra como ejemplo de superación de la exclusión social para diversas localidades en Brasil y en otros países, la finalidad de este estudio es reflejar sobre las estrategias de afrontamiento de la pobreza adoptadas por la comunidad del Nordeste de Brasil y su interfaz con la promoción de la salud. Inicialmente son presentadas la historia del conjunto y las estrategias colectivas de empowerment para el afrontamiento de la pobreza y la búsqueda del desarrollo humano. En seguida, se establece la relación de esas estrategias con los campos de acción para promoción de la salud. Finalmente, se considera que la responsabilización conjunta de la comunidad con su salud y su relación con el ambiente en que vive son medios de promover transformaciones que culminen con la conquista de un espacio social digno.

DESCRIPTORES: promoción de la salud; pobreza; enfermería

\section{ESTRATÉGIAS DE ENFRENTAMENTO DA POBREZA E SUA INTERFACE COM A PROMOÇÃO DA SAÚDE}

O empobrecimento populacional é uma realidade social cuja superação é necessária para que se possa pensar em saúde como um conceito positivo. Ante uma realidade que se mostra exemplo de superação da exclusão social para diferentes localidades no Brasil e em outros países, o presente estudo propõe-se a refletir sobre as estratégias de enfrentamento da pobreza adotadas pela comunidade da Região Nordeste do Brasil e sua interface com a promoção da saúde. Inicialmente são apresentadas a história do Conjunto Palmeira e as estratégias coletivas de empowerment para o enfrentamento da pobreza e busca do desenvolvimento humano. Em seguida, faz-se a relação dessas estratégias com os campos de ação para promoção da saúde. Considera-se que a co-responsabilização da comunidade com sua saúde e sua relação com o ambiente em que vivem são meios de promover transformações que culminem com a conquista de um espaço social digno.

DESCRITORES: promoção da saúde; pobreza; enfermagem

\footnotetext{
${ }^{1}$ Doctoral Student, Professor, Paraíba Federal University, Technical Health School Brazil, e-mail: simonehso@yahoo.com.br; ${ }^{2}$ Doctoral Student, e-mail: adelanemonteiro@hotmail.com; ${ }^{3}$ Doctoral Student, Professor, Regional University of Cariri; ${ }^{4}$ Doctoral Student,e-mail: danemel6@hotmail.com. Nursing Graduate Program; ${ }^{5}$ Advisor, Coordinator of the Faculty of Pharmacy, Dentistry and Nursing, Ceará Federal University, Brazil, e-mail: nvieira@ufc.br; ${ }^{6}$ Adivisor Free Lecturer, e-mail: grasiela@ufc.br; ${ }^{7}$ PhD in Nursing, Professor Department of Nursing, e-mail: Ibximenes@yahoo.com.br. Ceará Federal University, Brazil
} 


\section{INTRODUCTION}

This article presents the experience of a group of faculty and students in the subject Critical Analysis of Nursing Practices in Health Promotion, part of the Doctoral Course in Nursing, in the framework of the Graduate Nursing Program offered at Ceará Federal University, Brazil. One of the goals of this course is to assess indicators that characterize improvements in the population's health state and quality of life.

The course involves text analysis, group discussions and writing of essays about central themes and critical categories for health promotion on the basis of the discussions. The group jointly decided to visit the Conjunto Palmeira, a poor neighborhood located on the outskirts of Fortaleza, in the Brazilian Northeast, located at $22 \mathrm{~km}$ from the city's Commercial Center.

This report aims to reflect on the poverty coping strategies adopted by the community at the Conjunto Palmeira and their interface with health promotion.

\section{CONJUNTO PALMEIRA: ITS HISTORY IN COPING WITH POVERTY AND IN THE SEARCH FOR HUMAN DEVELOPMENT}

Reducing extreme poverty is one of the goals that was defined and internationally agreed upon in the Millennium Development Goals to achieve human development ${ }^{(1)}$.

The Brazilian Institute of Applied Economic Research - IPEA conceptualizes poverty as the situation of people below a certain economic standard, whose needs are not attended to. Any person below the poverty line, without sufficient resources to acquire the goods needed for survival would be considered as poor. This economic notion of poverty is still restricted and limited because being poor is much more than not having; it is, mainly, not being. Human development, in turn, must be understood as a process, in which human beings' potentialities are always developed and the opportunities for their development are expanded ${ }^{(2)}$.

Considering that the experiences and conquests achieved by the community at the Conjunto Palmeira constitute evidence of progress in this direction, we decided to visit that neighborhood so as to unveil, on the sport, a bit of the history of its struggle to overcome poverty. We consider that this reality is a reference point to assess a community's determination in the search to exercise citizenship, as well as a reference point to collectively share the search for and construction of prosperity in an increasingly interdependent world. Thus, we will address some facts that marked the history of this site, with a view to contributing to the reflection about collective strategies for empowerment and the conquest of citizenship.

We start with a bit of the history of how the neighborhood was created, after floods and evictions between 1973 and 1976, in Fortaleza-CE. People were homeless, staying at soccer stadiums and living in risk areas of different slums in the city. They neither had water nor electrical energy, sewage, collective transport or any type of public services and, moved by a feeling of social exclusion, they got organized in the search for better structural conditions. Thus, in 1981, the Association of Inhabitants of the Conjunto Palmeira was established which, through its members, started to demand infrastructure for the community ${ }^{(3)}$.

The inhabitants' engagement and organization power made the association carry out a door-to-door research, aimed at getting to know the reality of the neighborhood's economic conditions, and assessing that local commerce was not developing because the money was not circulating in the neighborhood itself. The inhabitants preferred to buy their products in large stores in the city center, because they had access to special financing conditions for their purchases. Consequently, the small businesses went broke, leading to unemployment and impoverishment of the people living in the neighborhood ${ }^{(3-4)}$.

In the description of the association members' reports, this population was characterized by illiteracy and low education level, unemployment, revenues below one minimum wage or no income whatsoever, a situation that placed them below the poverty line.

The urbanization of the area occurred at the same time as the poverty conditions of its inhabitants were aggravated, who were in no conditions to carry the costs of urbanization, such as: water and sewage, electricity and real estate tax (IPTU), as the large majority of families in the community were unemployed, underemployed, that is, living off eventual and informal activities, gaining less than one minimum wage. This made the poorest inhabitants sell their houses to those in better financial conditions ${ }^{(5)}$. 
In view of these evidences, in 1997, on the occasion of a community assessment seminar organized and held by the association, members decided to create a work creation project for the community. This project was inaugurated in January 1998 and was called Banco Palmas.

Its implantation initially occurred through a Ioan of approximately one thousand US dollars, granted by a local NGO (Cearah Periferia). The project was installed in a small room located in the headquarters of the association and started with a mere ten clients. Some months later, the projected received resources without any expectation of return through OXFAM international cooperation and GTZPRORENDA. At first, only two people managed the bank; nowadays, five community leaders take turns to be able to attend the population. Technical training was guaranteed through the Bank's earlier experiences in the PRORENDA project and through study circles held by the association, besides empirical knowledge of some local producers and merchants. When the work started, some members of the Bank received financial management training, offered by the local government ${ }^{(4)}$.

Development occurs when communities start to generate their own economic growth, through the development of community sense, participation and integration, conquered by organized groups in the community, instead of merely awaiting donations, politicians and governments ${ }^{(2)}$.

Hence, the Banco Palmas emerges as an integrated system that organizes and articulates the inhabitants of the Conjunto Palmeira to produce and consume in their own neighborhood, articulated in a network. It is a local development program that goes beyond the concession of micro-credit; it aims for the inhabitants' training and empowerment, arousing sensitivity for solidarity and cooperation, as a fair and sustainable development strategy model. Thus, it aims for the autonomy and emancipation of the subjects involved $^{(5)}$.

Local development is one of the strategies that involve the communities and, from this point onwards, integrated production processes are created, valuing local potentials (the people and the place). Hence, economic activities contribute to the group's local and cultural development ${ }^{(2)}$.

This initiative can be correlated with the ideas that the community moves from a naïve view to critical awareness, through the communication process, dialogue and knowledge sharing among the inhabitants, so as to put their practices in line with the world view and culture of all people involved, thus permitting behavioral change and social transformation $^{(6)}$.

Throughout the discussion process to consolidate this project, the group has learned countless lessons, among which we highlight the first: "it is no use to urbanize, to improve housing conditions in the slum, without an income creation alternative ${ }^{\prime \prime(5)}$. This shows the importance of this kind of project, which levers the construction of citizenship and contributes to human development, based on initiatives that grant sustainability to inhabitants at local level.

Economic development concentrates wealth in a minority and ends up segregating people; therefore, there is a need to promote other development styles, in which the local level is valued, community spaces are reconstituted and, from this point onwards, micro-development models and alternatives can oppose the hegemonic macro model, which reveals its inability to reach man, respecting human rights and achieving human development ${ }^{(2)}$.

The appeal to the community and the dissemination of the Banco Palmas' actions are carried out through local radio programs and member assemblies, attempting to stimulate mobilization for the constitution of a local solidary economy network. The network construction process is based on the mapping of the neighborhood's production and consumption, in consonance with the second lesson the group has learned: "the first step to cope with the income creation problem in a popular neighborhood is not to invest in production, but to organize consumers" ${ }^{\prime(5)}$

The third lesson refers to the credit line, and the group considers that: "what access to credit for the poorest is concerned, the neighbors constitute a true and legitimate social Credit Protection Service CPS $^{\prime \prime(5)}$. The micro-credit system, in turn, stimulates local production in order to satisfy existing consumption demands, in view of the fourth lesson learned: "poverty cannot be overcome without risks and without courage" ${ }^{\prime(5)}$.

The Banco Palmas' actions aim to reduce poverty through the creation of work and income, believing in what was learned during the constructing of the project and the daily experiences in community work. It is highlighted that "only daily life with the contradictions created by situations of extreme 
conclusion is capable of permitting knowledge and wisdom in order to effectively accomplish the most challenging of all managements: poverty management" ${ }^{\prime(5)}$

The Banco Palmas also expresses its understanding about the effect of capitalism on the low income population through the sixth lesson: "when micro-credit is granted in isolation and within the logic of the capitalist economy, making small producers mutually compete for the local market, this normally puts the borrower in a worse situation than he was before"$^{\prime(5)}$.

We can perceive through these lessons that the managers of the Banco Palmas, that is, the members of the community itself, consider that the projects should guarantee local sustainability and be directed at the community's needs. Considering this understanding, the group proposed another lesson: "in a popular neighborhood, domestic savings are primarily directed at buying food. Therefore, local production should focus on this area. Food products circulate more easily and oxygenate the solidarity network" ${ }^{\prime \prime}(5)$

For development to take place, it is not enough for the economy to grow but, mainly, this wealth needs to circulate, raising everyone's purchasing power and quality of life, based on the principles of human rights. The better people's quality of life, the greater the development process, meaning that it reached the human scale, satisfying their needs ${ }^{(2)}$.

In this sense, all activities proposed for the functioning of the Banco Palmas are directed at the inhabitants' social inclusion, based on work. However, the group perceived that many people were living below the poverty line and this finding contributed to yet another learning, which was highlighted in the eight lesson: "any local development projected implanted in poor neighborhoods needs to be concerned with how to involve the families living in misery. Normally, these are marginalized because they do not have the slightest conditions for civil participation and, often, through our projects, we reproduce yet another discrimination cycle $^{\prime \prime(5)}$.

It is important to highlight that all productive groups invest their surplus in the network itself, aiming for its growth and generating more jobs in the community. Another aspect that motivates collective growth is the dissemination of all project actions to grant visibility in other places, disseminating the conquests achieved until then and evidencing that this kind of projects can lead to social transformation.
Thus, the group believes that its work needs to be disseminated, which is expressed through the ninth lesson: "we need to disseminate very well everything we do in the peripheries, in order to understand a bit of the negative view of poor neighborhoods in common sense. Nobody knows what is not shown. And we are responsible for the image of our products"(5).

Hence, through the projects conceived by the bank managers who belong to the community, attempts are made to break the poverty cycle that exists in the Conjunto Palmeira, based on its inhabitants' inclusion in a project that, above all, deals with issues like citizenship, training and empowerment, to allow the inhabitants to be subjects of the social transformation and human development process.

Therefore, the Conjunto Palmeira, through its inhabitants' initiative, attempts to face poverty through an innovative strategy, the Banco Palmas, which develops its inhabitants' personal skills, favoring personal and social development, so as to provide information, education and training and improve individual aptitudes.

We consider that, although social justice has not actually been established yet, the community, even when facing a wide range of problems, did not get alienated but, on the opposite, joined forces to establish a social transformation process that is still ongoing, whose desire and anxiety to achieve personal and social development still seem to constitute the bases of that community's motivations.

\section{STRATEGIES TO COPE WITH POVERTY AND THEIR RELATION WITH HEALTH PROMOTION}

The greater a country's social inequality, the more it will affect quality of life and, consequently, the health of society in general and individuals and their families in particular. The impoverishment of the Brazilian population exerts significant influences on people's quality of health, as individual health is not limited to its biological and psychological dimensions; on the opposite, it is directly related with human beings' living conditions and is influenced by the countries' social and economic policies ${ }^{(7)}$.

Health Promotion is defined as "the training process of the community to act in the improvement of its quality of life and health, including greater 
participation in the context of this process" ${ }^{\prime(8)}$. People should get individually or collectively involved, as equal partners, with a view to achieving integral health ${ }^{(9)}$.

The prerequisites of quality of life established during the First International Conference on Health Promotion, held in Ottawa (Canada) and ratified at subsequent conferences, include: peace; housing that attends to the basic need for shelter; access to an efficient education system, which favors the formation of citizens; availability of a sufficient quantity of food to attend to biological needs; promotion of children's and adolescents' growth and development; replacement of the work force; sufficient income to attend to basic needs and the above prerequisites. These need to be guaranteed by educational, agricultural, environmental and urban transport policies, directed at the broad objective of health, quality of life and human development, guided by democratic values of justice and equity ${ }^{(10)}$.

When a dignified life is guaranteed to all, which ensures the health of their families, including wellbeing, food, clothing, housing, medical care, security, rest and leisure, development will be reaching the human scale. And if this reality is experimented in a specific place, it may actually be happening ${ }^{(2)}$.

We consider that the fights and conquests of the community at the Conjunto Palmeira are in line with the action areas of health promotion, among which the strengthening of community action deserves emphasis, which starts with the community's actual and concrete participation in the election of priorities, in decision making and in the elaboration and development of strategies to reach a better health level. The force that moves this process derives from the community's real power, from their possession of and control over their own efforts and destinies ${ }^{(8)}$.

The initiatives described in the entire historical context that culminated in the creation of the Banco Palmas and the development of the Conjunto Palmeira point towards rules that maintain their interface with health promotion as it was conceived in Ottawa, which acknowledges individuals as the main source of health, needing support and training at all levels to allow them, their families and friends to maintain a good health state. In this sense, the community is the fundamental spokesperson in terms of health, living conditions and general well-being ${ }^{(8)}$.

It is important to highlight that, based on this premise, health is conceived on the basis of a broader understanding, not exclusively related to health care, but involving quality of life, in terms of socioeconomic conditions like housing, basic sanitation and access to the job world.

Hence, favoring the empowerment of people to allow them to make plans for their own lives means considering health as a positive concept, which goes beyond a healthy lifestyle and seeks a global wellbeing, free from mental, biological and social diseases, as the possibilities of overcoming adversities start to show their availability to those people who find themselves as reflexive and active subjects in society and, therefore, capable of changing the reality they are living in.

We consider that any change and enabling of man includes education, which constitutes the base for all economic development that departs from the human being. Therefore, above all, development strategies should prepare people, through education, to be a protagonist of their development process $^{(2)}$.

Thus, another action area of health promotion should be highlighted - skills development, directly related with helping people in the increasing control of their life. The advice is given that personal and social development can be conquered through information, education for health and intensification of vital abilities, which makes it possible for the population to exert greater control over its own health. This task must be carried out at schools, homes, work places and other community spaces. Actions must occur through educational, professional, commercial and voluntary organization, as well as through governmental institutions ${ }^{(8)}$.

In the Conjunto Palmeira, examples of favoring personal and social developments are the results obtained through strategies like the creation of complementary programs to support the network, originating training schools, an incubator for women in risk situations, an urban agricultural laboratory, exchange clubs with social currency, among others. The Community School and Joint Socioeconomics Palmatech - should be highlighted, whose mission is based on the satisfaction of human needs, departing from a new economic ethics, based in socio-supportive practice and in which participants are trained through courses and workshops in joint company management, like in the base of the community consultant course for joint businesses, elaboration of small projects, among others ${ }^{(4)}$. 
Through this and other projects, to the extent that they take ownership of the knowledge, the community members are getting empowered, an individual and community empowerment, as the conquered improvement benefit these two areas, thus strengthening the assertion that power and knowledge are synonyms. Hence, the poverty coping strategies, the rescue, or who known even the initial experience in exercising citizenship, are reflected as actions to promote the inhabitants' health.

Other strategies are also proposed, which the mentors of the Banco Palmas call products, used to favor the community's development. Among these, we can mention: the credit card, markets, stores, encouragement of consumers in the neighborhood to buy from local producers, as well as a collective purchasing system organized among inhabitants of different neighborhoods, prioritizing the purchase of local products.

It is important to highlight that, although this is a bank, the economic view in force in this kind of institutions, that is - profit, was subjugated, given room to principles and values they call supportive economy, which aims for local development by improving the quality of life of people who are part of the community. This same community is the subject that reflects about its reality and about the possibilities of overcoming the adversities, establishing the nexus between critique and action.

Facing the reality presented in the actions implemented by the Banco Palmas puts us in a position of convergence with Frei Betto's optimism by affirming the possibility that is indicated for the quantum recovery of the historical subject, based on a holistic view, with ideals, without utopias and not submitted to market laws ${ }^{(11)}$.

The situation presented at the Conjunto Palmeira, particularly related to the Banco Palmas, evidences the overcoming of what Frei Betto refers to, even if in a micro-dimension when compared to the global context, of turning capital into a mechanism at the service of human happiness, and not an instrument to dominate the poor, as this is found in the bank's projects and action, which aim to empower the subjects to conquer a dignified social space ${ }^{(11)}$.
We agree that human development will only fully take place when public policies reorient their priorities towards the social, actually benefiting man, making it feasible to respect human rights ${ }^{(2)}$. Therefore, it should be highlighted that there is a lack in terms of health promotion with respect to the creation of healthy public policies, in view of the need we perceive for the actions carried out at the Conjunto Palmeira to be put in practice, constituting public policies that manage to make these benefits practicable for all people, mainly the poorest ones.

\section{CONCLUSION}

The community focused on in this research protagonizes an innotivate local development of collective social inclusion, where its inhabitants conquer poverty through socialized choices and opportunities, reflected in the valuation of their resources, talents and in the community's self-esteem.

The Banco Palmas constitutes the symbol of possible opportunities to purchase material and social goods, in which this community managed to raise itself again towards human development.

The strategies used by the community at the Conjunto Palmeira demonstrate that health promotion actions in poverty situations should take into account by what means people face their needs and how, together, they can exercise their citizenship and be capable of producing transformations in their realities. We believe that this kind of experiences stand out by the endogenous development of the community, by the co-accountability with its living and health conditions and by its relation with the environment (physical, social).

Thus, human development does not only cover having access to the means necessary for an adequate living standard but, above all, people needs political, economic and social freedom, the opportunity to be creative and productive.

We conclude that, each day, this community is conquering space and getting empowered, with a view to breaking the poverty cycle and improving income through local social development projects to promote human development.

\section{REFERENCES}

1. Pereira ALF. As tendências pedagógicas e a prática educativa nas ciências da saúde. Cad Saúde Pública 2003 setembro-outubro; 19(5):1527-34.
2. Programa das Nações Unidas para o Desenvolvimento. Relatório do Desenvolvimento Humano. A água para lá da escassez: poder, pobreza e a crise mundial da água. New York (USA); 2006.

3. Coriolano LNMT. A exclusão e a inclusão social e o turismo. Rev Turismo y Patrimônio Cultural 2005 junho; 3(2):295-304. 
4. Associação dos Moradores do Conjunto Palmeira. Memória de nossas lutas, V.2. Fortaleza (CE): ASMOCONP/ PRORENDA; 1998.

5. Associação dos Moradores do Conjunto Palmeira. Desenvolvimento local sustentável: o exemplo da Associação de Moradores do Conjunto Palmeira com o Banco Palmas. Fortaleza (CE): ASMOCONP/PRORENDA; 2000.

6. Melo Segundo JJ de Neto, Magalhães S. Bairros pobres, ricas soluções: Banco Palmas ponto a ponto. Fortaleza (CE): Expressão Gráfica; 2003.

7. Freire P. Educação e mudança. $24^{a}$ ed. Rio de Janeiro (RJ): Paz e Terra; 2001.

8. Rosa AS, Cavicchioli MGS, Brêtas ACP. O processo saúdedoença-cuidado e a população em situação de rua. Rev Latinoam Enfermagem 2005 julho-agosto; 13(4):576-82.

9. Ministério da Saúde (BR). Secretaria de Políticas de Saúde. Projeto Promoção da Saúde. As cartas da Promoção da Saúde. Série B. Textos Básicos em Saúde. Brasília (DF): Ministério da Saúde; 2002.

10. Ministério da Saúde (BR). Secretaria de Assistência à Saúde. Departamento de Assistência e Serviços da Saúde. Coordenação de Saúde na Comunidade. Avaliação da Implantação e Funcionamento do Programa Saúde da Família - PSF. Brasília (DF): Ministério da Saúde; 2000.

11. Westphal MF. O movimento Cidades/Municípios Saudáveis: um compromisso com a qualidade de vida. Ciênc Saúde Coletiva 2000 janeiro-fevereiro; 5(1):39-51.

12. Betto F. Indeterminação e complementaridade. In: Castro G, Carvalho EA, Almeida MC. Ensaios da complexidade. Porto Alegre (RS): Sulina; 1997. p. 47-53. 